\title{
COVID-19 Tracking Mobile Application at ITCG
}

\section{Aplicación Móvil de Rastreo COVID-19 en el ITCG}

OCHOA-ORNELAS, Raquel†*, ÁLVAREZ-HERNÁNDEZ, María Isabel, VELASCO-LUJÁN, David and VARGAS-DE LA CRUZ, Alma Janeth

Tecnológico Nacional de México/Instituto Tecnológico de Ciudad Guzmán

ID $1^{\text {st }}$ Author: Raquel, Ochoa-Ornelas / ORC ID: 0000-0003-1824-5789, Researcher ID Thomson: S-4687-2018, arXiv Author ID: Raquel Ochoa, CVU CONACYT ID: 668976

ID $1^{\text {st }}$ Coauthor: María Isabel, Álvarez-Hernández / ORC ID: 0000-0001-7801-9439, arXiv Author ID: mialvarezh, CVU CONACYT ID: 804384

ID $2^{\text {nd }}$ Coauthor: David, Velasco-Luján / ORC ID: 0000-0002-7644-3348, arXiv Author ID: velascodavid, CVU CONACYT ID: 1167262

ID $3^{\text {rd }}$ Coauthor: Alma Janeth, Vargas-De La Cruz / ORC ID: 0000-0001-7636-1732, arXiv Author ID: Alma_Vargas

DOI: $10.35429 / J I T .2021 .26 .8 .6 .13$

Received: August 10, 2021; Accepted December 30, 2021

\begin{abstract}
Objectives: Implement a mobile application to control COVID-19 in all its variants, containing or reducing the spread of the virus during the return to face-to-face classes at the ITCG. Methodology: The project was developed in Android Studio using different libraries and technological resources. You have access to a web server with a MySQL database. The application allows scanning the QR code of the visited site from the mobile application, reporting a positive case and vaccine reactions, monitoring any unusual adverse effects, as well as receiving notifications via SMS. Contribution: Contain the advance of the virus, avoiding saturating health systems, monitoring users in the event of any eventuality. The application was distributed to the student community of the Technological Institute of Ciudad Guzmán (ITCG) during the application of the first dose of the AstraZeneca vaccine, to monitor any symptoms, as well as positive cases during the return to face-to-face classes.
\end{abstract}

COVID-19, Mobile app, Tracking

\section{Resumen}

Objetivos: Implementar una aplicación móvil para controlar el COVID-19 en todas sus variantes, conteniendo o reduciendo la propagación del virus durante el regreso a las clases presenciales en el ITCG. Metodología: El proyecto fue desarrollado en Android Studio utilizando diferentes bibliotecas y recursos tecnológicos. Tiene acceso a un servidor web con una base de datos en MySQL. La aplicación permite escanear desde la aplicación móvil el código QR del sitio visitado, reportar caso positivo y reacciones de vacunas, dando seguimiento a cualquier efecto adverso inusual, así como recibir notificaciones vía SMS. Contribución: Contener el avance del virus, evitando saturar los sistemas de salud, monitoreando a los usuarios ante cualquier eventualidad. La aplicación fue distribuida a la comunidad estudiantil del Instituto Tecnológico de Ciudad Guzmán (ITCG) durante la aplicación de la primera dosis de la vacuna AstraZeneca, para dar seguimiento a cualquier síntoma, así como de los casos positivos durante el regreso a clases presenciales.

\section{COVID-19, Aplicación móvil, Rastreo}

Citation: OCHOA-ORNELAS, Raquel, ÁLVAREZ-HERNÁNDEZ, María Isabel, VELASCO-LUJÁN, David and VARGAS-DE LA CRUZ, Alma Janeth. COVID-19 Tracking Mobile Application at ITCG. Journal Information Technology. 2021. 8-26: 6-13

\footnotetext{
$\dagger$ Researcher contributing as first author.
} 


\section{Introduction}

Projects designed with open source are used in different types of computing devices, from small applications to complex projects. For these projects to be successful, the continuous participation of professional communities is required (Drost-Fromm \& Tompkins, 2021). In recent years, mobile devices have had a positive impact on society. Even in commerce, a strategic context has been incorporated into mobile marketing through attractive advertisements generating more sales, since it engages consumers in an interactive way responding to requests for products and services. More than $50 \%$ of users connect to the Internet through these devices, so companies use this channel to send notifications and attract more consumers, achieving a better relationship with them (Branisso, 2021).

The latest technological innovations have improved the daily lives of many people (Chou, 2021). For example, in medicine, a wireless system based on epidermal electronics was designed to measure a non-invasive physiological signal through a sensor, allowing a patient to be continuously monitored, including information not observable by the technological current in medical devices ( Lee, 2021).

On the other hand, mobile applications have been used efficiently in the management of chronic diseases, helping to maintain control, and monitoring of cases (Andreas et al., 2019). Mobile applications are accessible and tolerable for the population that has a mobile device (Kondylakis et al., 2020).

To combat the contagion of COVID-19, governments in different countries have promoted the creation of applications that allow tracking and data collection through mobile devices. The most common functionalities of these mobile applications are to generate location maps in real time, report symptoms directly to health and education organizations about COVID-19 (Sharma \& Bashir, 2020). The applications are created to reduce physical contact in hospitals and thus prevent infections, being an effective tool for citizens and health personnel (Kondylakis et al., 2020).

\section{Project background}

The WHO (World Health Organization), on December 31, 2019, was notified about cases of pneumonia in China, later identified as COVID19. On March 11, 2020, the WHO Director General declared COVID-19 a pandemic due to the high levels of spread and severity as it spread across various countries and continents. (Fernández et al., 2020).

When the COVID-19 disease started and spread around the world in just a few months, it caused several deaths. Hospitals in many cities were overwhelmed to care for the sick. Isolation is the most effective strategy to contain the growth of infections, since more than $60 \%$ of infections arise from asymptomatic people. COVID-19 causes respiratory symptoms, nausea, abdominal pain, vomiting, diarrhea, anosmia, and ageusia. Some of the forms of contagion occur through close contact and contamination of the environment. Therefore, strict protection measures must be taken with infected people (Otero et al., 2020).

During the health emergency, countries like Korea developed applications to track the mobility of contacts to detect new cases through mobile communications and the global positioning system (GPS). The increase in the use of mobile devices and the development of information technology, promote a new approach to mitigate pandemics (Hernández et al., 2020). Therefore, immediate contact tracing is essential to isolate infected people and reduce the rate of new outbreaks (Hellewell et al., 2020).

Technological development has contributed to improving the way of identifying, tracking, and managing pandemics. Digital communication technologies, having the ability to process and systematize large amounts of information, have responded by contributing to mitigating risks by treating diseases efficiently in any emergency worldwide (Wilson \& Jumbert, 2018).

This strategy is feasible when more than $80 \%$ of the population uses smart devices and tracking technology is available. In this way, this type of project has an impact by reducing the high economic costs by having to suspend commercial and economic activity due to the pandemic (Hernández et al., 2020). 


\section{Objectives}

\subsection{General objective}

Implement a mobile application to control COVID-19 in all its variants, containing or reducing the spread of the virus during the return to face-to-face classes at the ITCG.

\subsection{Specific objectives}

- $\quad$ Prevent the increase in infections.

- Follow up on positive cases and side effects of vaccines.

- $\quad$ Reduce the rate of new outbreaks of COVID-19 in its different strains in the student population.

- $\quad$ Reduce saturation in hospitals.

- Support in the reduction of high economic costs avoiding suspending academic activity.

\section{Theoretical framework}

\subsection{Android}

Android Studio is a development environment (IDE) to develop mobile applications focused solely on the Android operating system and is based on IntelliJ IDEA (Android Developers, 2021). It offers different functions and tools for development and productivity such as:

- $\quad$ A flexible build system based on Gradle.

- $\quad$ A fast and feature-laden emulator.

- A unified environment capable of developing applications for all Android devices.

- Ability to push code and resource changes to the running application without restarting it.

- GitHub integration and templates that help compile common application functions.

- $\quad$ Compatibility with $\mathrm{C}++$ and NDK.

SharedPreferences is an object that is attached to a file that contains key-value pairs and provides easy reading and writing methods. This object can be private or shared and is managed by framewok (Android Developers, 2021).
Intent is a messaging object that can be requested to initiate an action from another application component (Android Developers, 2021). Intents objects facilitate communication between components in several ways and are used in three main cases:

- $\quad$ Start an activity: an activity represents a screen in an application. The intent describes the activity to be started and contains the necessary data to do so.

- $\quad$ Start a service: a service does not require an interface and is a component that performs background operations.

- Broadcast an emission: a broadcast is a notice. The system transmits event emissions, for example, when the device is charged.

App permissions help support user privacy, protect access to restricted data such as system status and user contact information, and other restricted actions such as connecting to a linked device or recording audio. To declare a permission, the <uses-permission> element is included in the manifest file (Android Developers, 2021).

\section{2 $Q R$ code}

The QR code was launched in 1994 by Denso Wave and adopted in the automotive industry in Japan, streamlining tasks in manufacturing processes. Subsequently, many food, pharmaceutical and contact lens companies incorporated the use of the QR code for inventory control, in order to highlight production and logistics processes. This has led various industries to respond to consumer demands, allowing logistics and processes to be completely transparent. QR codes contain three squares in the corners for the reader to detect the position of the code. Its structure is divided into function patterns and a coding region. Function patterns contain information to decode, such as location pattern, alignment pattern, timer pattern, and spacer (Camarena and Guillén, 2017).

\subsection{Volley}

Hébuterne (2018) explains that the Volley library is part of the com.andorid.volley.toolbox package. This library allows you to optimize calls to web services, proposing two solution options to obtain a RequestQueue instance. 
In common cases, the static method Volley.newRequestQueue is invoked. The Volley library uses RPC-like operations to complete the user interface. It integrates efficiently with any protocol. Eliminates the need to write standard code, which makes application development more efficient (Android Developers, 2021).

\subsection{ZXingScannerView}

It is a tool used in Android Studio to scan QR codes from a mobile device. The ZXingScannerView.ResultHandle class belongs to the ZXing library and is responsible for using the device's camera to scan the $\mathrm{QR}$ code, process the image to identify it, as well as decode it (Camarena and Guillén, 2017).

The ZXingScannerView.ResultHandle interface is used in the Android project and includes a built-in handleResult() function with an empty data type. The parameter that returns the result of the handleResult() function is precisely the scanned value (Patil, 2017).

\section{Methodology}

\subsection{Analysis}

The role of the mobile application was defined through the following options available to the user:

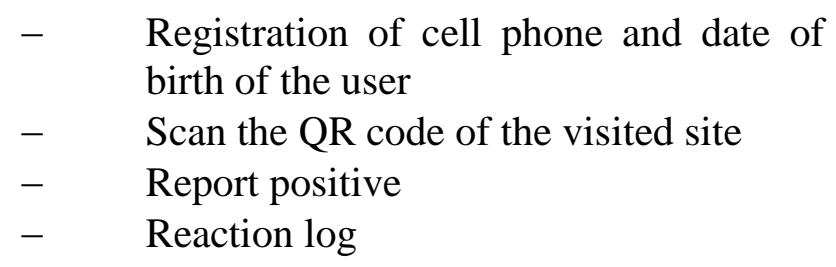

\subsection{Design}

During design, the database was created in MySQL on a cloud server, which is made up of the following data stores:

$\begin{array}{ll}- & \text { Users } \\ - & \text { Places of interest to visit } \\ - & \text { Positive cases } \\ - & \text { Visitor's log } \\ - & \text { Reactions } \\ - & \text { Vaccination posts }\end{array}$

The application was designed integrating colors and components that allow a better functionality and experience for users in each of the options. The ITCG sites of interest were defined according to the institutional map. See Figure 1:

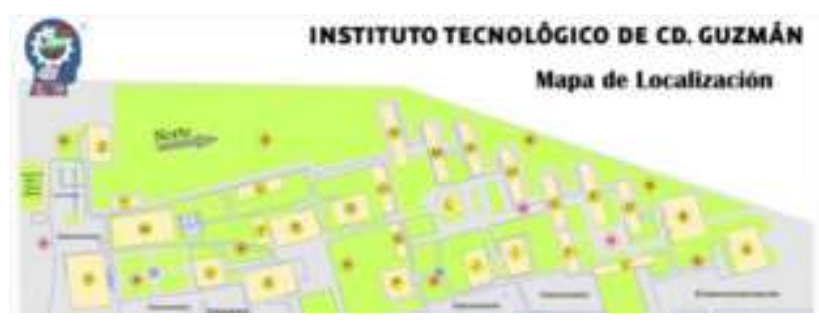

Figure 1 Institutional map

Subsequently, the QR codes for each location were generated using the page www.codigos-qr.com. This QR code generator is free, so it has no digital property registration. See Figure 2.

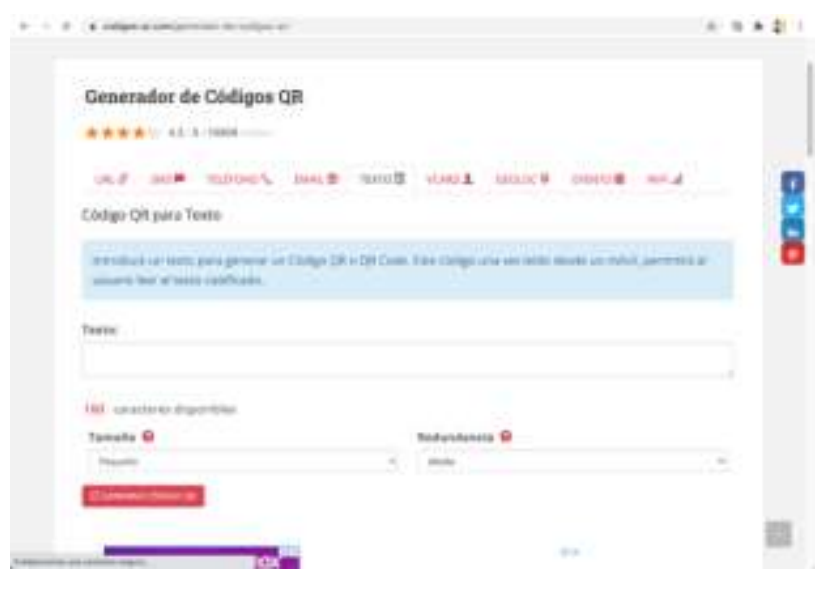

Figure 2 QR Code Generator

The option that was selected was Text with the following structure: idSite / Name / Location. Figure 3 shows an example of the QR code composed of ID, Classroom and Building (1/ Classroom 1 / Building A):

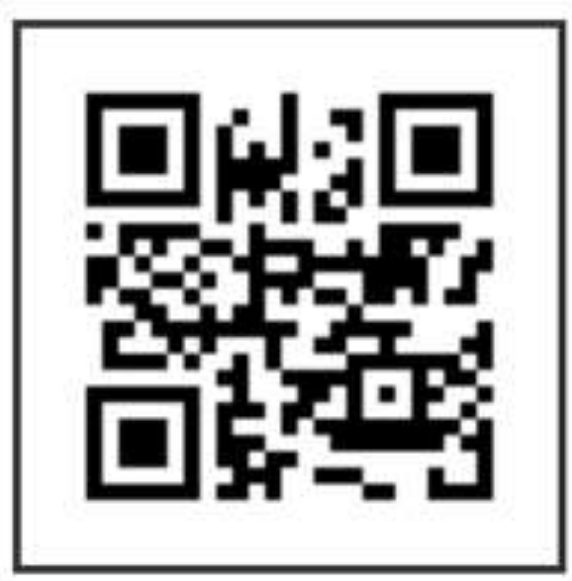

Figure 3 QR code example

OCHOA-ORNELAS, Raquel, ÁLVAREZ-HERNÁNDEZ, María Isabel, VELASCO-LUJÁN, David and VARGAS-DE LA CRUZ, Alma Janeth. COVID-19 Tracking Mobile Application at ITCG. Journal Information Technology. 2021 
Once the QR codes of the places of interest were created, covers were printed that were installed in each of the entrances to the classrooms and main offices. The information corresponding to the sites of interest was registered in the database to complement the tracking with a visit log that identifies the id of the visited site, user id and date-time of the visit.

\subsection{Coding}

One of the most relevant options of the developed application was to scan the QR code and then send the information of the visited site with the user and the date to the central database. To scan the QR code, the ZXingScannerView.ResultHandler interface must be implemented. In a previous step, the corresponding libraries are incorporated into Build.gradle. Permissions to access the device's camera were given in the AndroidManifiest file.

Pressing the button to start scanning executes the following code invoking camera startup to preview the QR code scan. Subsequently, the apk to be distributed was generated, being necessary to access the compilation settings within Android Studio and thus perform a task of "assembling" and selecting the "gradle" of the project.

As a complement to this project, a web application was developed simultaneously to monitor and administer the system, with access to the same database in MySQL. The platform was developed in PHP, Bootstrap, JavaScript, jQuey and Ajax. It includes an option that sends mass notifications through SMS messages to the devices of users who traveled in the same places, dates, and times as a positive case reported. To address this problem, an Altiria API was implemented that facilitates the task of sending SMS alerts from a PHP web page to mobile devices registered in the database.

\subsection{Tests}

Finally, different types of unit and exhaustive tests were carried out where some errors in the code were detected and resolved in a timely manner. The mobile application was distributed to the students of the Tecnológico Nacional de México campus Instituto Tecnológico de Ciudad Guzmán during the vaccination of the first dose of the AstraZeneca vaccine against COVID-19, for people between 18 and 29 years old.
In this process, users did not detect any flaws in the application by reporting their symptoms.

\section{Results}

Below are some screens of the mobile app running. Figure 4 shows the general options offered by the mobile application to ITCG students:

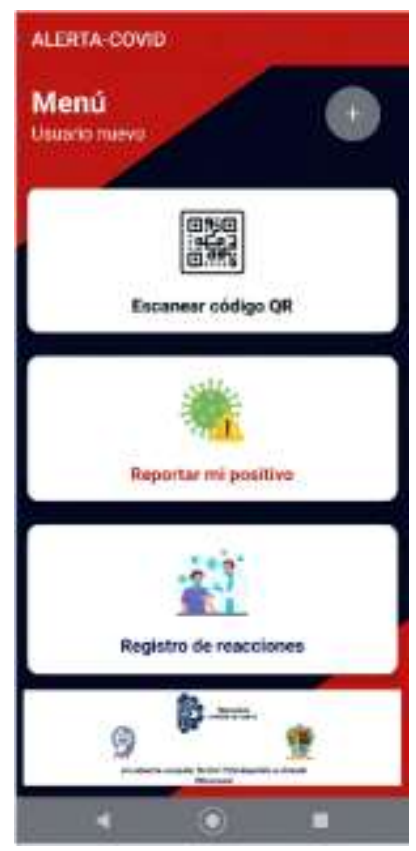

Figure 4 Main options

When starting the application, it is essential to register the user's cell phone, gender, and date of birth on a single occasion. This allows a user record to be maintained in the central database of the system. In Figure 5 the application for the entry of registration data is presented:

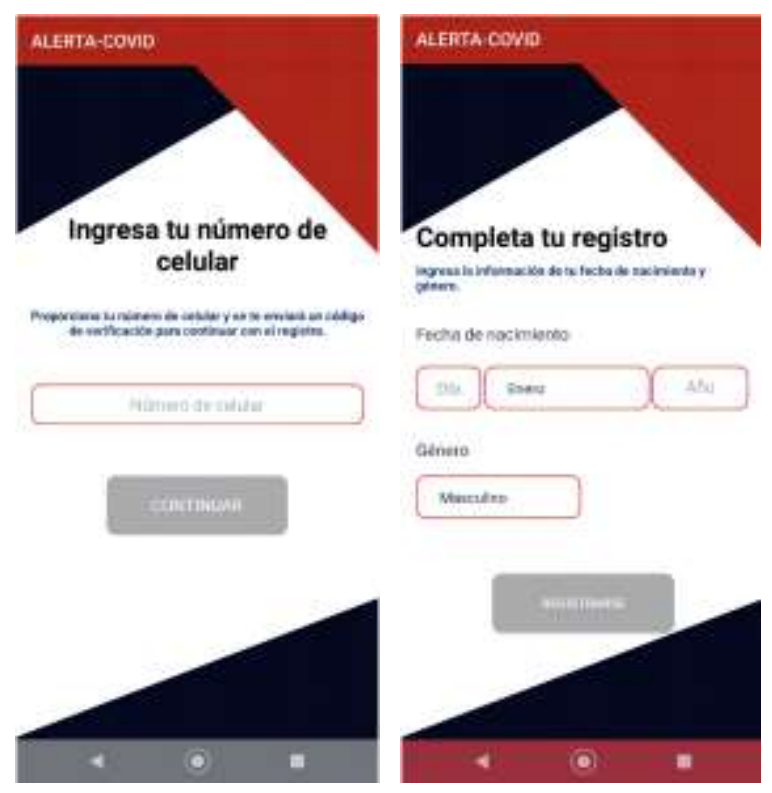

Figure 5 Cell phone record, gender, and date of birth

OCHOA-ORNELAS, Raquel, ÁLVAREZ-HERNÁNDEZ, María Isabel, VELASCO-LUJÁN, David and VARGAS-DE LA CRUZ, Alma Janeth. COVID-19 Tracking Mobile Application at ITCG. Journal Information Technology. 2021 
By selecting the Scan QR Code option, the application sends a message to the user to allow access to the camera. If the user accepts, the scan is captured showing the information of the visited site. Finally, the information is obtained from the code that includes id, description of the site, location, as well as the user id and date-time of the visit, being registered in the central database. Figures 6 and 7 show the QR code scan option:
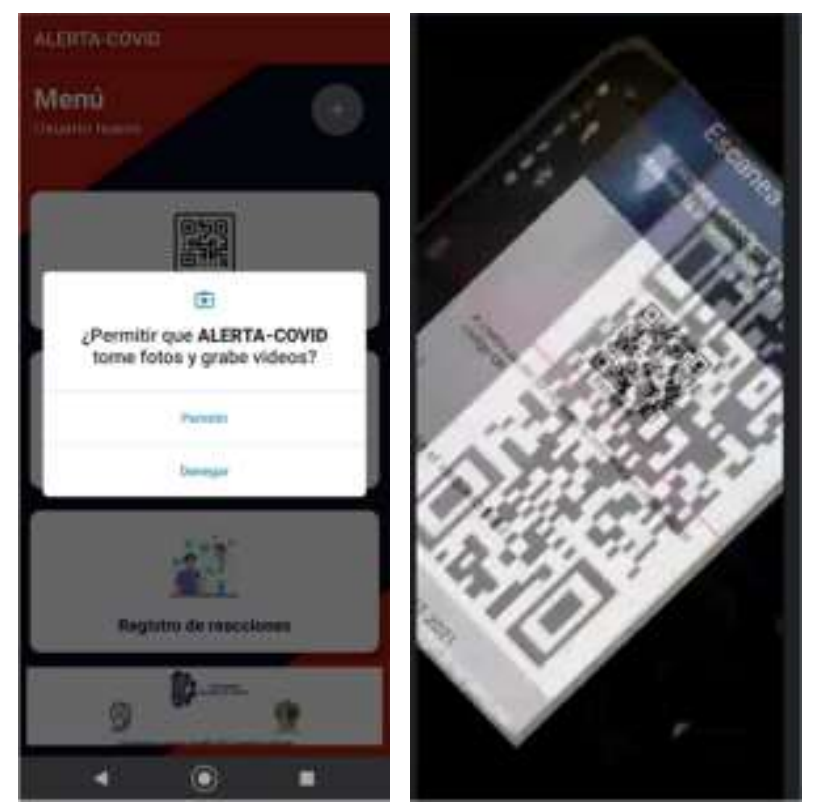

Figure 6 QR code capture

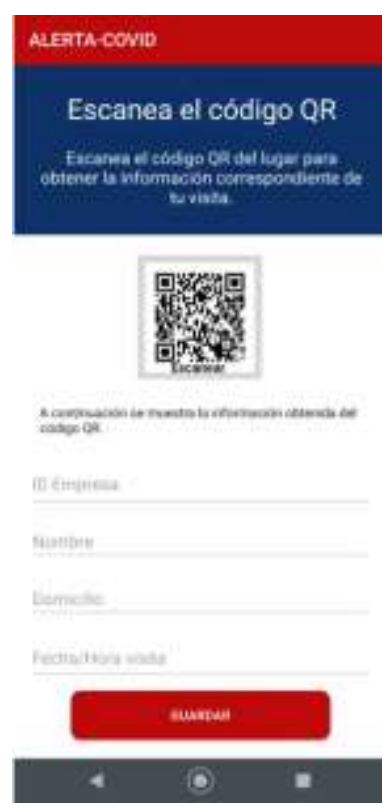

Figure $7 \mathrm{QR}$ code capture and information registration

In the option to report my positive, the user selects the start date of the symptoms and subsequently reports the case. See Figure 8.

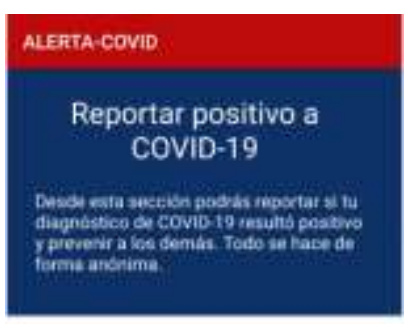

Selecciona la fecha de inicio de sintomas.

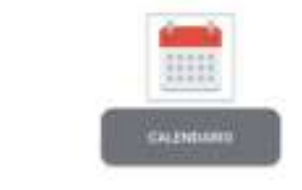

Feche seteccionada

aromancese

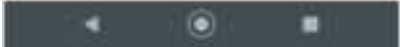

Figure 8 Report positive case

In the reaction registry, the user must select the vaccination post, then the cell number data is displayed, the received vaccine is selected by entering the date of application and the reactions. See Figure 9.

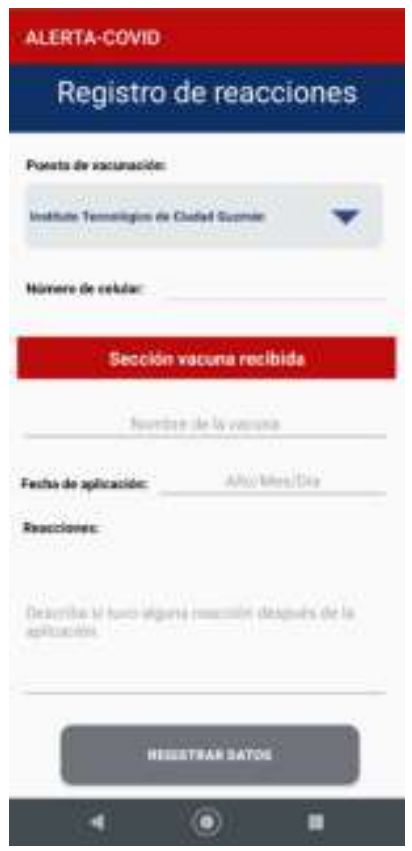

Figure 9 Reaction log

In case of receiving a positive report from any of the users, a mass notification is sent to the exposed contacts through an SMS from the monitoring platform on the web. See Figure 10. 


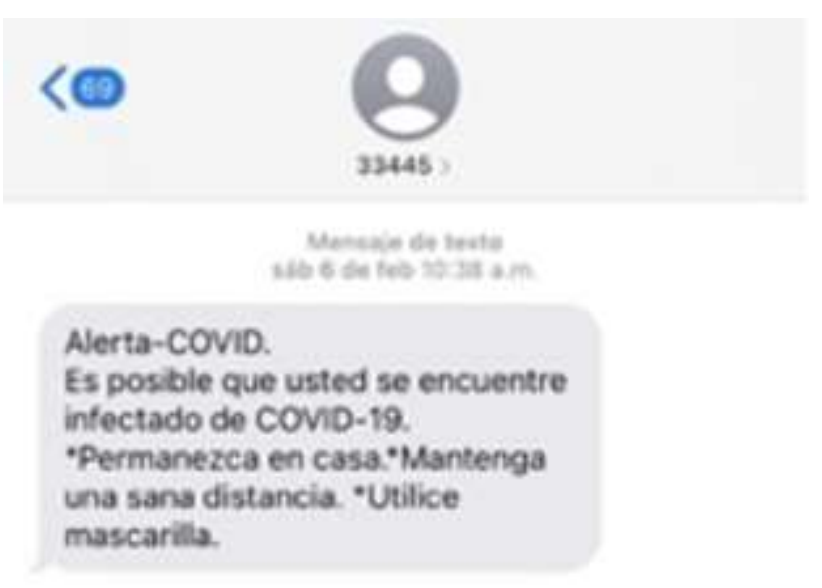

Figure 10 Notification of possible contagion by SMS

Figure 11 shows a statistic of the reactions reported in a sample of 100 students during the application of the first dose of the AstraZeneca vaccine at the ITCG:

\section{Astrazeneca Reactions}

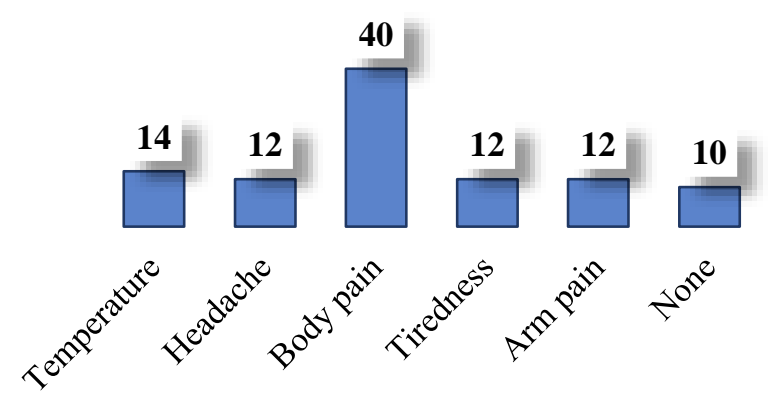

Figure 11 AstraZeneca reactions

\section{Thanks}

The authors thank the Tecnológico Nacional de México for the support granted to carry out this research project registered with code 10892-21P.

\section{Conclusions}

One of the greatest challenges humanity has faced over time is controlling pandemics. In the current emergency, information and communication technologies have played an important role in countering the spread of COVID-19. The presented project was developed by students and professors of ITCG's Computer Engineering career. The application offers a practical and simple alternative for users, allowing them to continue with activities without affecting or paralyzing them.
The implementation in the institution is resumed a few days after the return to the faceto-face classes, generating valuable experience, since it will serve as a basis to be disseminated in other sectors, in addition to promoting the development of other types of projects.

\section{References}

Andreas , T., Haridimos , K., Konstantinos, V., Dimitrios , T., Nicos , M., \& Kazem , R. (Diciembre de 2019). Features, outcomes, and challenges in mobile health interventions for. International Journal of Medical Informatics, 12.

doi:https://doi.org/10.1016/j.ijmedinf.2019.103 984

Android Developers. (1 de Octubre de 2021). Guías para desarrolladores. Obtenido de Guías para desarrolladores: https://developer.android.com/guide

Branisso, D. S. P. (2021). From Clicks to Bricks: Effects of Mobile Location (Doctoral dissertation, PUC-Rio).

Camarena Gutiérrez, A. B., \& Guillén Algarra, J. M. (2017). Ajedrez en dispositivos móviles: códigos QR.

Chou, J. R. (2021). A TRIZ-based productservice design approach for developing innovative products. Computers \& Industrial Engineering, 161, 107608.

Drost-Fromm, I., \& Tompkins, R. (2021). Open Source Community Governance the Apache Way. Computer, 54(04), 70-75.

Fernández Sosa, J. F., Aguirre, V., Delía, L. N., Thomas, P. J., Corbalán, L. C., \& Pesado, P. M. (2020). COVID-19: un análisis comparativo de Apps. In XXVI Congreso Argentino de Ciencias de la Computación (CACIC)(Modalidad virtual, 5 al 9 de octubre de 2020).

Hébuterne, S. (2018). Desarrolle una aplicación Android: programación en Java con Android Studio. Ediciones ENI.

Hellewell, J., Abbott, S., Gimma, A., Bosse, N. I., Jarvis, C. I., Russell, T. W., ... \& Eggo, R. M. (2020). Feasibility of controlling COVID-19 outbreaks by isolation of cases and contacts. The Lancet Global Health, 8(4), e488-e496. 
Hernández-Orallo, E., Manzoni, P., Calafate, C. T., \& Cano, J. C. (2020). Evaluating how smartphone contact tracing technology can reduce the spread of infectious diseases: the case of COVID-19. Ieee Access, 8, 99083-99097.

Kondylakis H, Katehakis D, Kouroubali A, Logothetidis F, Triantafyllidis A, Kalamaras I, . . . Tzovaras D. (09 de Diciembre de 2020). COVID-19 Mobile Apps: A Systematic Review of the Literature. J Med Internet Res, 22. doi: $10.2196 / 23170$

Lee, K. H. H. (2021). Mechanoacoustic Sensing at Suprasternal Notch (Doctoral dissertation, Northwestern University).

Menni, C., Klaser, K., May, A., Polidori, L., Capdevila, J., Louca, P., ... \& Spector, T. D. (2021). Vaccine side-effects and SARS-CoV-2 infection after vaccination in users of the COVID Symptom Study app in the UK: a prospective observational study. The Lancet Infectious Diseases.

Otero, W., Gómez, M., Ángel, L. A., Ruiz, O., Marulanda, H., Riveros, J., ... \& Bastidas, M. (2020). Procedimientos endoscópicos y pandemia COVID-19. Consideraciones básicas. Revista Colombiana de Gastroenterologia, 35(1), 65-75.

Patil, A. V. (2017). Programming $Q R$ code scanner, communicating Android devices, and unit testing in fortified cards. California State University, Long Beach.

Sharma, T., \& Bashir, M. (Agosto de 2020). Use of apps in the COVID-19 response and the loss of privacy protection. Nature Medicine, 3. doi:https://doi.org/10.1038/s41591-020-0928-y

Wilson, C., \& Jumbert, M. G. (2018). The new informatics of pandemic response: humanitarian technology, efficiency, and the subtle retreat of national agency. Journal of International Humanitarian Action, 3(1), 1-13. 